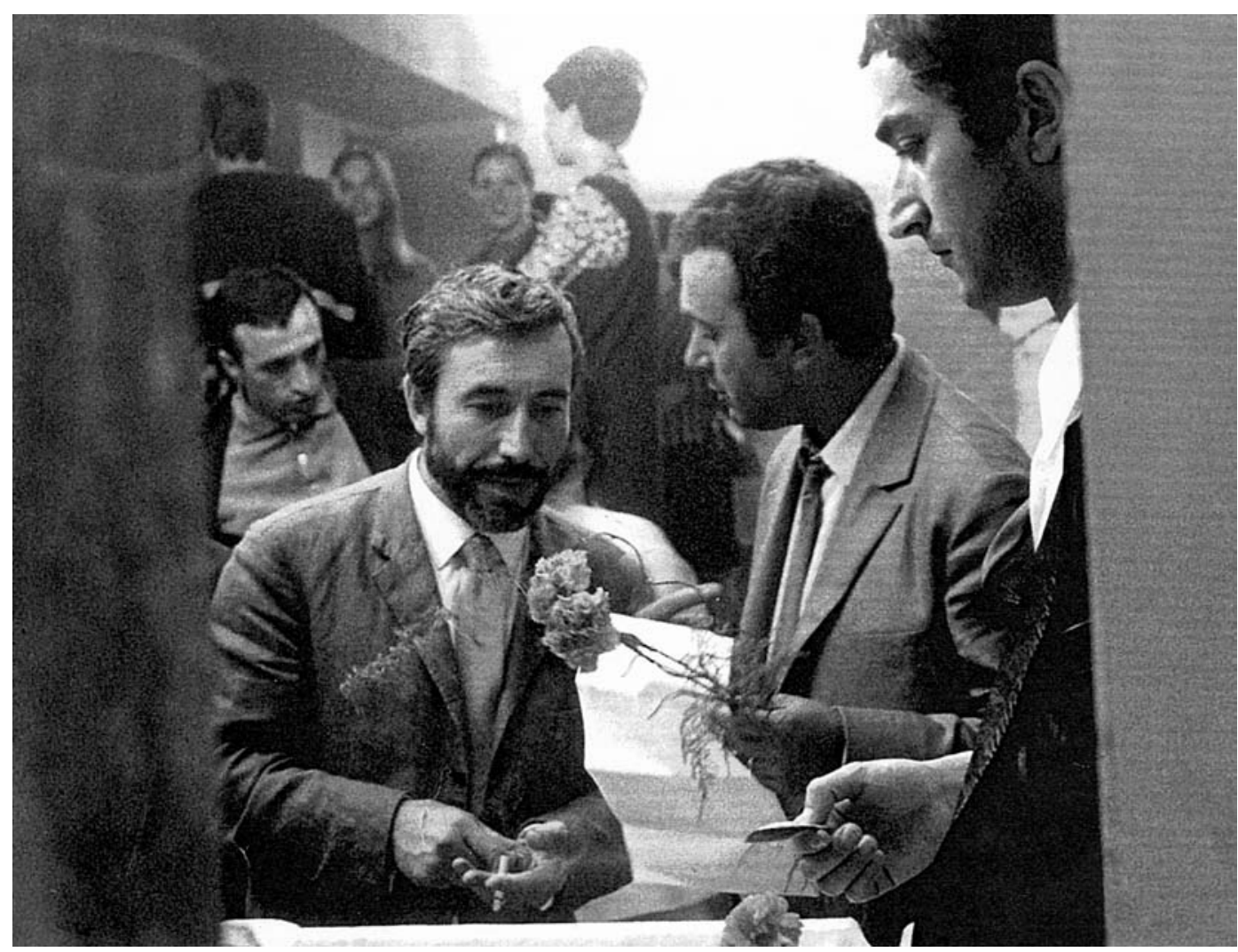

\title{
Primeiro Acto - Clube de teatro
}

\section{Eduardo Pedrozo}

Primeiro Acto:

Nascido em 1968 - 1969

Morto em data incerta.

Visto de 2007

\section{A génese}

Em fins de Junho de 1968, seis ou sete amigos reuniramse, à noite, na cave da Livraria Espaço, em Algés, para ouvir a proposta que um deles - Armando Caldas - trazia.

Tratava-se de criar um grupo de teatro amador, com sala própria, para o qual se tinha já apalavrado um espaço para arrendar, em Algés, os baixos de um prédio ainda em construção. Era preciso concretizar o arrendamento do espaço, construir aí um teatro, legalizar uma entidade jurídica e começar os ensaios de um primeiro espectáculo.

Para tudo isso havia que arranjar adesões, trabalho voluntário e dinheiro, mas sobretudo era necessário e muito dificil enfrentar e vencer o sistema burocráticopolicial que o Estado Novo opunha a qualquer veleidade de associativismo cultural, para mais com objectivos de fazer espectáculos públicos.

Estava-se nos últimos meses do salazarismo, em breve viria a Primavera marcelista, que acabou por ser a nesga por onde esta iniciativa se esgueirou para ver a luz do dia, antes do recrudescer da repressão que antecedeu a queda do regime, em 1974.

0 grupo inicial lançou-se ao trabalho, discutindo opções e diligências.

E foi numa das reuniões seguintes que se fez uma opção determinante de toda a realização e vida futura do projecto. A ideia inicial era um grupo de teatro amador cujo nome seria G.A.T.A., Grupo de Teatro Amador de Algés. Mas outra ideia se contrapôs e tomou a dianteira - uma associação cultural "de largo espectro"; um clube de espectadores, aberto a iniciativas de teatro, e outras, internas e externas, fazendo do teatro a construir um espaço de liberdade cultural.

Nada mais belo, mas também nada mais utópico no contexto repressivo da sociedade do Estado Novo! E que no entanto se tornou realidade.

\section{E porquê Primeiro Acto?}

0 nome surgiu logo a seguir - um número da revista espanhola de teatro Primer Acto, em cima da mesa, levou à sua imediata escolha. E o conceito traduziu-se na expressão "Clube de Teatro".

O Primeiro Acto - Clube de Teatro passou então por uma longa fase de gestação. Como clube cultural teve de obter autorização do Ministério da Educação, seguindose a escritura notarial e restantes formalidades. 0 grupo inicial assumiu-se primeiro como comissão organizadora e depois como primeira direcção - não-eleita - que geriu
Eduardo Pedrozo foi co-fundador do Primeiro Acto e seu primeiro Presidente da Direç̧ão. 
0 público na estreia de

Antigona,

fot. J. Marques.

\footnotetext{
de Jean Anouilh,

enc. Armando Caldas,

Primeiro Acto, 1969 (José Capela, Vitor Viçoso

Madalena Pestana,

entre outros),

fot. J. Marques.
}

Antigona o clube até 1971. 0 elenco da Comissão

Organizadora/Direcção foi assim constituido: Presidente: Eduardo Pedrozo; Vice-Presidente: Armando Caldas; Secretário: Jorge Ferreira da Silva; Tesoureiro: Viriato Portugal; Vogais: Ezequiel Silva, José Luís Madeira, Alberto Guerra.

0 teatro - desenhado por uma equipa de que sobressai Nuno Teotónio Pereira - começou a ser construido, e a primeira peça - Antígona, de Anouilh - arrancou em ensaios de leitura no Sport Algés e Dafundo, cujo Presidente, na época, comentava, com desconfiança política, todo o projecto, mas permitiu os ensaios.

Cumpridos todos os passos da penitência burocrática, a data oficial de fundação foi 9 de Janeiro de 1969. Apoios oficiais, subsídios - apenas um subsídio da Câmara de Oeiras (presidida por uma pessoa que se dizia não afecta ao regime, fruto do marcelismo)! A subsídio-dependência era então um conceito desconhecido. Era substituido pela sobrevivência face à Censura, à polícia política e ao aparelho do Estado, que via a Cultura como instrumento da subversão política. Apoios privados - muitos. Desde os intervenientes na construção - arquitectos, engenheiros e voluntários em geral, todos sem remuneração - até empresas fornecedoras, a poios em dinheiro, e as quotas dos que se iam associando, juntando as dividas adiadas; e assim o projecto foi em frente.

Com a legalização, a Imprensa, a Rádio e a Televisão passaram a noticiar o andamento da iniciativa. Entre os aderentes começaram a contar-se muitos nomes da intelectualidade e das áreas políticas opostas ao regime.

\section{Ascensão e declínio}

Quando Antígona estreou, o impacte foi enorme. 0 teatro quase en rond, intimista, sem proscénio, sem qualquer desnivel entre o palco e a plateia, uma atmosfera de onde
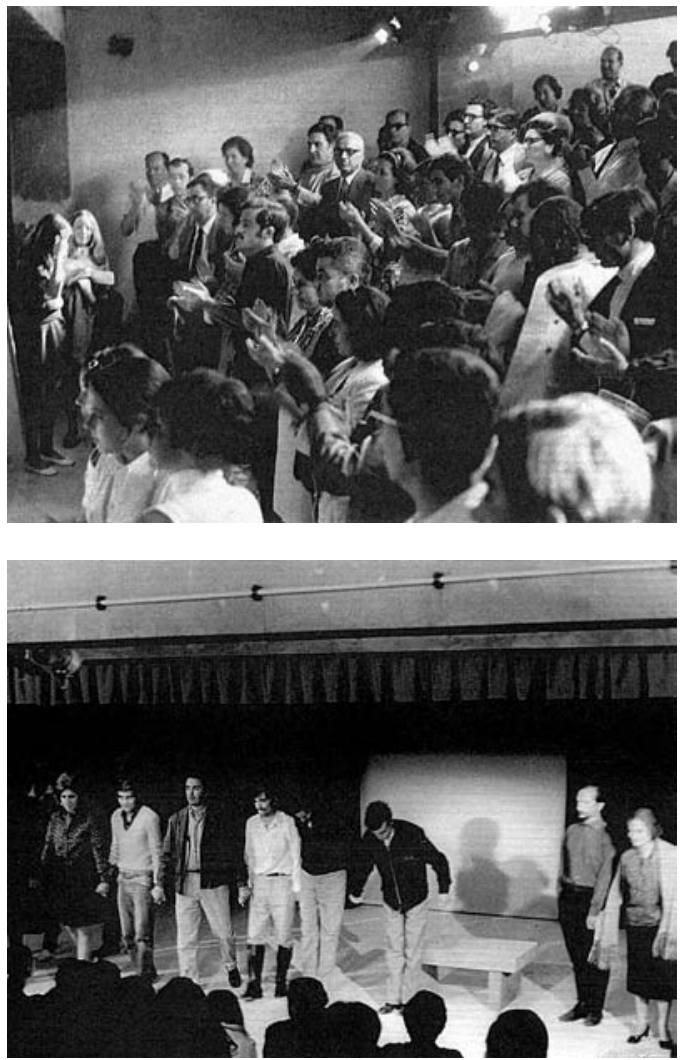

se evolava um sortilégio de lugar de liberdade num território opressivo, e a Antígona de Madalena Pestana, uma revelação como actriz-força da natureza, cujo grito de liberdade ultrapassou as paredes do Primeiro Acto convocaram gente de todos os lados, por vezes incrédula, ou fascinada, perante algo que parecia fora dos limites consentidos.

Como um fenómeno de massas, este arranque propiciou uma catadupa de criatividades várias, iniciativas, propostas. De certo modo, passou a ser chique intelectual ir ao Primeiro Acto. Mais ainda: fazer algo no 1. ${ }^{\circ}$ Acto. Era como se fosse um elemento essencial para o currículo de cada um! Artistas de todas as artes, exilados políticos de passagem, poetas...e grupos de teatro - quer internos (chegou a haver dois a trabalhar ao mesmo tempo) quer externos, e corais, ciclos de cinema, exposições, tudo! Não se recusava um convite para vir e colaborar e apareciase sem convite, para ver e experimentar estar ali.

Agostinho da Silva vem do Brasil e logo vai ao Primeiro Acto. Ary dos Santos faz uma noite de poesia que, recordada agora, só se consegue imaginar no pós-25 de Abril. Cantores e poetas vão ao $1 .{ }^{\circ}$ Acto - Adriano Correia de Oliveira Natália Correia, Francisco Fanhais, Fernando Assis Pacheco, Tossan, José Carlos de Vasconcelos...

Zeca Afonso é proibido.

Jorge Peixinho faz a música da Antigona e depois experimenta criação musical em tempo real, diante do público; José Ernesto de Sousa arrasta Almada Negreiros para a sua iniciativa Almada, nome de guerra; Alves Redol e José Cardoso Pires, Vasco Graça Moura, Saramago,

Santareno, Ernesto de Melo e Castro, e outros, aparecem, são sócios, colaboram.

Uma onda que tem outros contornos, talvez menos visiveis, mas determinantes. Em Maio de 68 tinha havido em Paris a grande vaga libertária que alastrou em França 


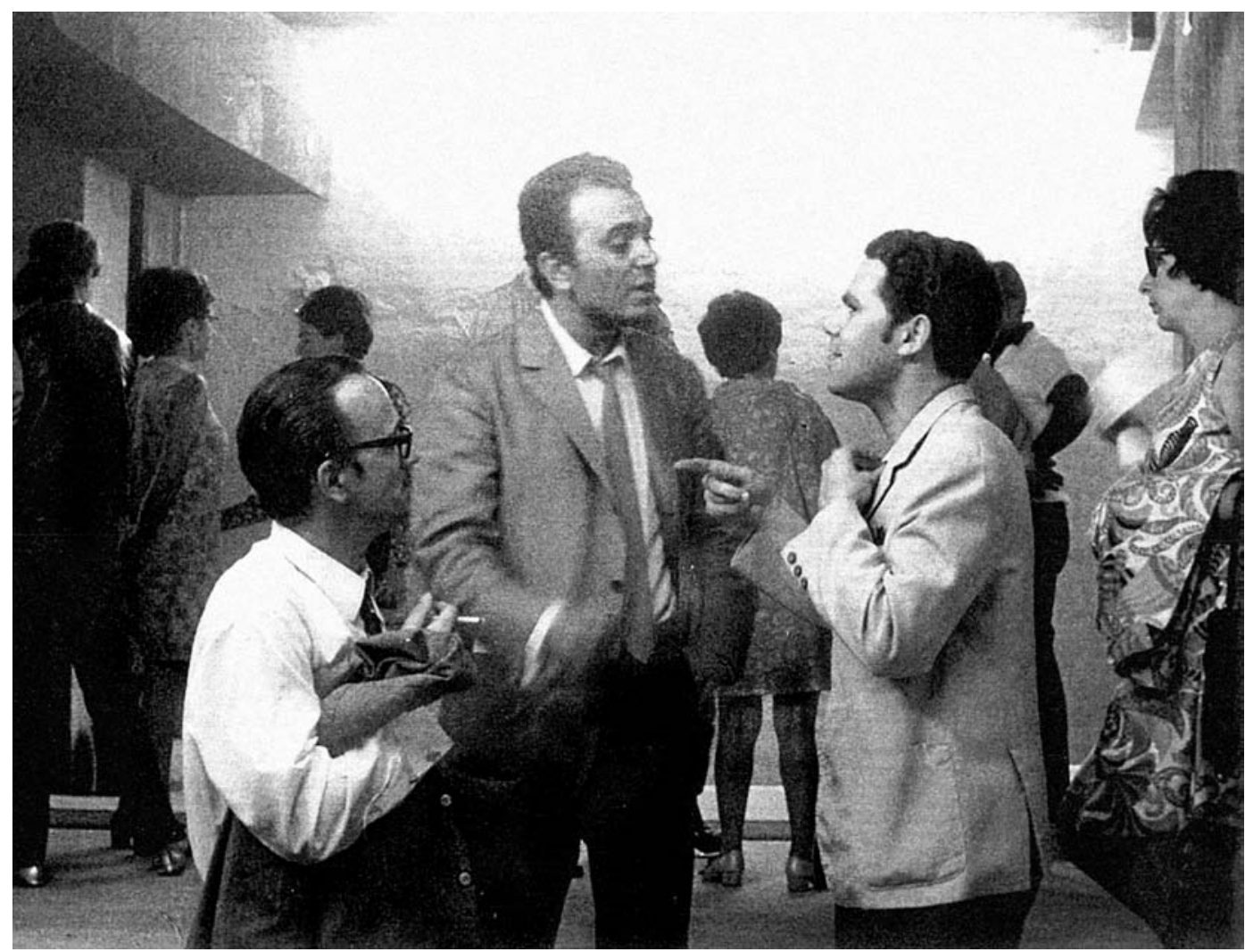

e foi influenciando a Europa. Para muitos jovens em Portugal, esse espírito libertário era um caminho alternativo para o combate ou a evasão face ao regime. E, se os fundadores do $1 .{ }^{\circ}$ Acto andavam pelos trinta anos, e viviam um "oposicionismo tradicional", havia uma segunda "camada" que aguardava vez e tinha menos dez anos. Os seus nomes não eram ainda sonantes, mas apareciam e intervinham - e talvez tenham sido influentes no pendor libertário que foi marcante na vida do clube. Entre eles, Vitor Viçoso, que veio a ser Presidente a partir de 1971, António Borga e Carlos Morais, juntos na "Comissão de Teatro", que fazia "marcação cerrada" à Direcção.

A dialéctica que opunha mais velhos e mais novos produzia, nessa altura, em grande parte, a identidade do 1. ${ }^{\circ}$ Acto e pode explicar parte do seu sucesso. Símbolo dessa juventude, Mário Viegas, fazendo a tropa ali perto, despia a farda para comparecer no $1 .{ }^{\circ}$ Acto, dizer poemas e falar livremente contra a guerra.

Entre 1969 e 1970, o Primeiro Acto produziu quatro espectáculos - Antígona, de Anouilh, e Histórias para serem contadas, de Osvaldo Dragun, ambos encenados por Armando Caldas, No princípio será a carne, de Manuel Grangeio Crespo e Nós não estamos algures, poemas de Luiza Neto Jorge, dirigido por José Ernesto de Sousa. Em 1971, a produção mais importante foi A cantora careca de lonesco, encenada por Carlos Nery.

Estes espectáculos fizeram dezenas de representações e intercalavam com vindas ao Primeiro Acto de outros grupos - Proscenium, dirigido por Pedro Lemos, Campolide, por Joaquim Benite, Bonecreiros ${ }^{1}$, Teatro Experimental de Cascais ( Carlos Avilez) são exemplos dessa época de intensa actividade.

Ao mesmo tempo, criaram-se aulas de educação musical para crianças, pelo método Carl Orff, e uma Oficina de Artes Plásticas para crianças. Lançou-se um curso livre de expressão corporal, dado pela bailarina Inês Palma, que teve grande adesão.

Com menos visibilidade mas não menos importância, criaram-se comissões e grupos que organizavam exposições de fotografia, sessões de cinema e de música e elaboravam documentação sobre teatro e um boletim informativo.

Nesses três anos seria rara a noite ou o fim-de-semana sem actividade. Um aspecto notável dessa actividade foi ter-se criado a tradição de, no final de todos os espectáculos ou sessões, haver sempre um tempo para debate.

Sabendo-se que esses debates eram ilegais, logo clandestinos, pois dependeriam de autorizações, nunca concedidas, e que a porta estava aberta e ninguém os ignorava, era evidente que havia uma tolerância calculada por parte das autoridades, talvez para, com certa comodidade, ouvirem o que se dizia e pensava em círculos restritos e bem identificados, pois a grande massa dos espectadores não ficava para o debate.

Em finais de 1971, novos dirigentes (Vitor Viçoso, Carlos Nery e outros) procuraram continuar o percurso, mas o impulso e o entusiasmo iniciais estavam a entrar em declínio, a situação política e a repressão agravavamse e, quando se deu o 25 de Abril, a vida interna deteriorouse, o $1 .{ }^{\circ}$ Acto parecia deixar de fazer sentido, foi caindo sucessivamente em mãos de grupos que aproveitavam o desinteresse dos antigos activistas e facilmente ingressavam como sócios e se apoderavam do clube.

Ainda antes do 25 de Abril, assinala-se 0 celeiro do Império (nome disfarçado de "Milho para o oitavo exército"), encenado por Jorge Listopad, com participação de Samuel.

Depois, foram altos e baixos, episódios para esquecer, tentativas honestas de reabilitação, mas nada de relevante, sendo de mencionar que houve combates de antigos sócios para serem reintegrados após abusivas eliminações.
'Foi a 21 e 22 de

Outubro de 1972 que passou no Primeiro Acto o espectáculo A grande cegada dos touros, mulheres e fado, que contava no elenco com Mário Jacques, Vicente Galfo, José Gomes, Fernanda Barreto, Diniz Cintra, Maria de Jesus Aranda, Fernanda Alves e Glicinia Quartin. A concepção do espectáculo contou com a colaboração de Luiza Neto Jorge (letra das canções), Jorge Silva Melo (recolha de textos) e Deniz Cintra (música). 


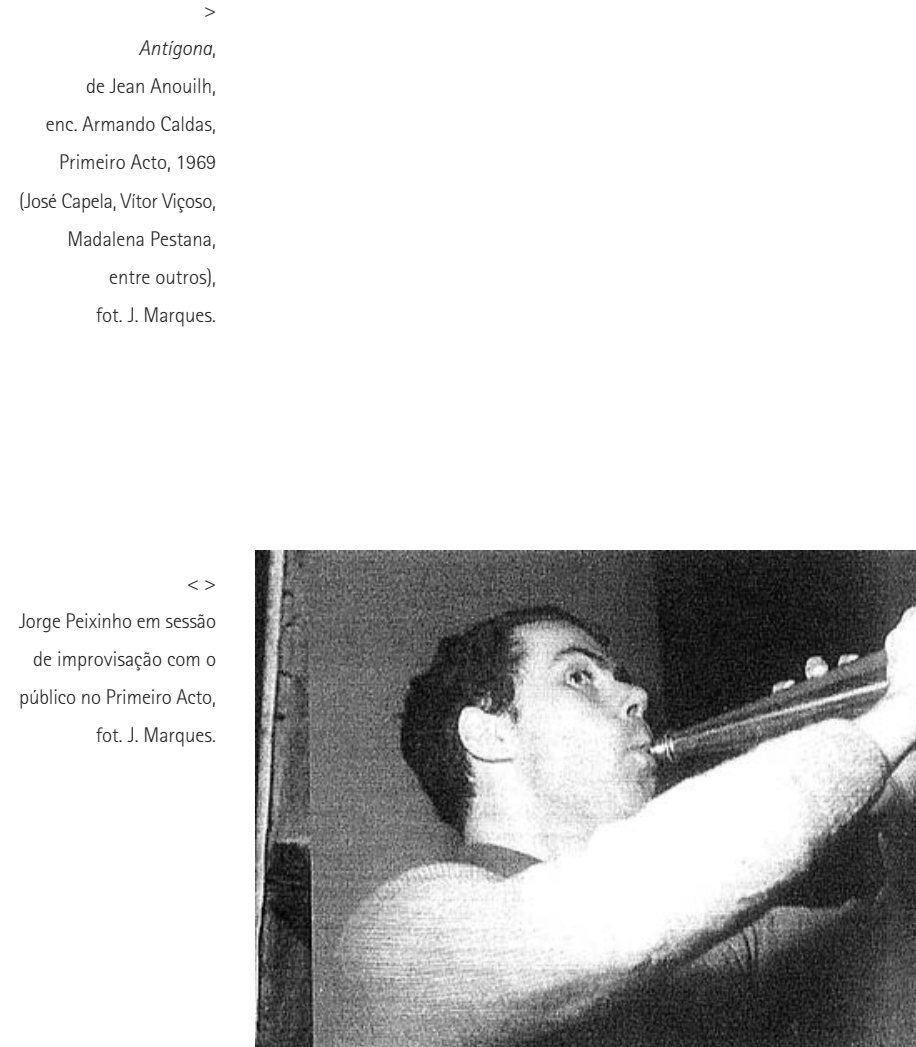

Armando Caldas propôs e realizou alguns espectáculos, como um convidado externo - comédias de Labiche, Feydeau e Almeida Garrett, Tchekov e uma adaptação de Humilhados e ofendidos, de Dostoievski.

As portas fecharam-se de vez ao $1 .{ }^{\circ}$ Acto do passado e mais tarde tudo se esfumou e desapareceu: clube, sócios, recheio do teatro.

Quando a Câmara Municipal de Oeiras comprou o espaço ao primitivo senhorio, já não encontrou inquilino, e transformou o teatrinho, esventrado e roubado dos seus conteúdos, em Auditório Amélia Rey Colaço, onde apenas uma placa evoca o "espaço de liberdade" que ali fervilhou entre 1969 e 1973

\section{Sob a égide do Primeiro Acto}

0 núcleo activo do 1. ${ }^{\circ}$ Acto diluiu-se quando, com o 25 de Abril, todos se envolveram em outras frentes. Este foi um factor importante para o declínio.

Quando se pretendeu usar a qualidade de sócio do 1. ${ }^{\circ}$ Acto para ali desenvolver novos projectos de teatro, os novos dirigentes eliminaram sócios e recusaram abertura a novas iniciativas, com a excepção referida de algumas peças "autorizadas" a Armando Caldas.

Este, com o apoio de outros antigos activistas do 1. Acto, começou a realizar novos espectáculos fora do clube - em salas do Palácio Anjos, cedidas pela Câmara de Oeiras - intitulando-se o grupo "Primeiro Acto - Marginalizados".

Mais tarde, e após uma evolução agitada, sucedeuIhe o "Intervalo - Grupo de Teatro", que a Câmara de Oeiras patrocinou, recusando-Ihe, no entanto, o teatrinho do $1 .{ }^{\circ}$ Acto e cedendo-Ihe o Auditório Lurdes Norberto, em Linda-a-Velha.

Armando Caldas e o seu Intervalo têm desde então assumido a sucessão do Primeiro Acto e ali se celebram os aniversários marcantes da sua fundação em 1969,
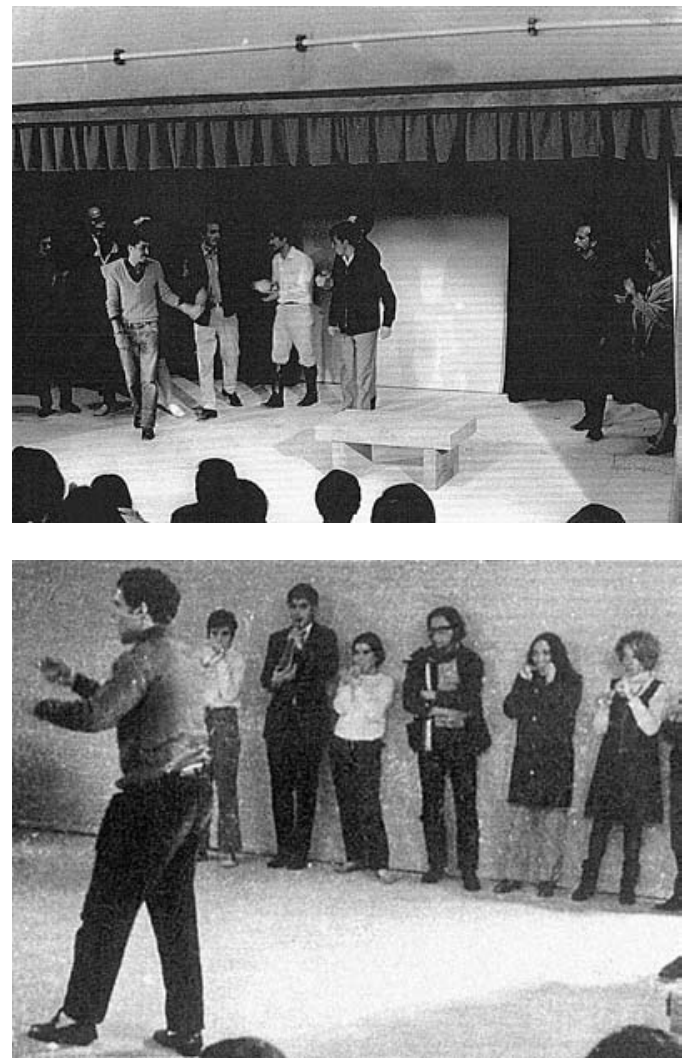

sempre com participação significativa de figuras da Cultura portuguesa que viveram aqueles tempos e sabem quanto deve a nossa liberdade cultural a esse Clube de Teatro, concebido em segredo na cave da Livraria Espaço.

\section{Quantos sócios teve o Primeiro Acto?}

É difícil estimar quantos sócios teve o $1 .{ }^{\circ}$ Acto - deve ter atingido os 800, segundo a documentação disponivel, nem todos cumpridores do dever de pagar a quota de vinte escudos - longe, portanto, dos números que por vezes se mencionam, mil, dois mil ou mais.

Num longo relatório de 1972, o Conselho Fiscal afirmava que 800 fora o número máximo alcançado, tendo já nessa ocasião descido para 433. Mas a sala comportava cento e cinco lugares sentados e, com o interesse e também a curiosidade que traziam sempre mais gente, atingia-se com facilidade o total de mil a dois mil espectadores, ao fim de duas semanas de representação.

\section{Realizações emblemáticas}

Não é de mais repetir - o $1 .{ }^{\circ}$ Acto não foi um grupo ou companhia de teatro, não exprimia uma linha estética ou programática, apenas uma comunhão de ideais, consentânea com a sua abertura a iniciativas, e a sua "produção" resultava de oportunidades coerentes com esses ideais.

Se há que eleger realizações emblemáticas do e no $1 .{ }^{\circ}$ Acto, há três ou quatro indiscutiveis, por razões diferentes: Antígona, verdadeiro ícone do Clube e do seu esplendor, revolucionário e efémero, encenação de Armando Caldas; as duas intervenções de Manuel Grangeio Crespo, pelo insólito iconoclasta; e A cantora careca, de lonesco, dirigida por Carlos Nery, pelo seu rigor e eficácia.

Antigona foi escolhida pelo encenador antes da criação do Clube e precisamente como elemento essencial da sua 


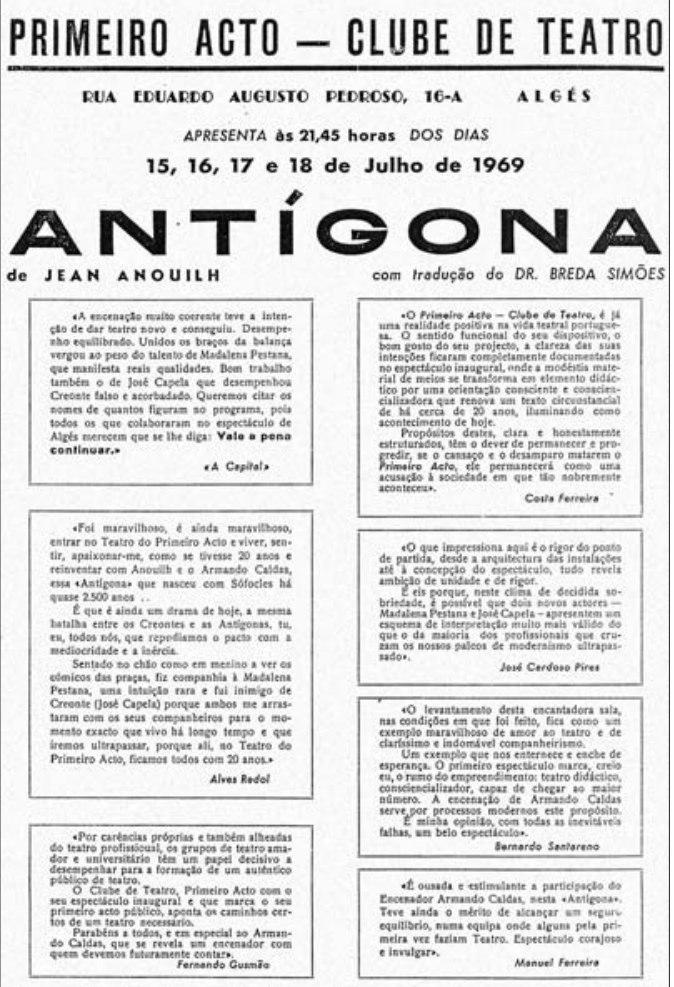

Se gosta de bom Teałro, não perca este especráculo!

fundação. Apesar de reservas postas à escolha da versão de Anouilh, a encenação exigente, a interpretação poderosa de Madalena Pestana e, sem dúvida, a mensagem de revolta que o público sentia intensamente no momento grave que se vivia no País, tudo se conjugou para abrir em glória e de forma irrepetivel a história do Primeiro Acto, num espectáculo com força e sem concessões ou elementos supérfluos.

Já Manuel Grangeio Crespo era um assumido marginal: dirigira uma companhia de teatro underground em Nova lorque, onde se dizia que vivera numa comunidade hippie. 0 seu primeiro espectáculo foi a leitura encenada de um texto seu, publicado em livro - No princípio será a carne. Devido à previsível recusa da Censura, optou-se pelo risco de fazer os espectáculos sem quaisquer licenças. Crespo tinha uma doença neurológica - que o matou - que o mantinha numa cadeira de rodas. Quando chegava ao $1^{\circ}$ Acto, que não tinha qualquer ajuda à mobilidade, era preciso transportá-lo ao colo pela escada, o que se fazia no meio de grandes gargalhadas. Esta bravura que 0 caracterizava era vibrante nas suas realizações. A leitura encenada do texto envolvia diversas luzes "pirilampos" de carros de polícia, espalhadas pela sala, vários gravadores de som passando a mesma fita, gravando e reproduzindo em sequência e, last but not least, a destruição sistemática de dezenas de exemplares do livro, em cada sessão!

Não se tratava de um grande texto ou de uma grande encenação. Aqui, foi o insólito que marcou um espectáculo imaginativo, de épater le bourgeois, mas que não exibia rigor nem solidez.

Meses depois, Crespo propôs e obteve autorização para conduzir um colectivo espontâneo na construção improvisada de um novo espectáculo. Intitulou ele o projecto de Jogos dramáticos, desenrolando-se uma vez por semana. 0 recrutamento dos participantes decorreu

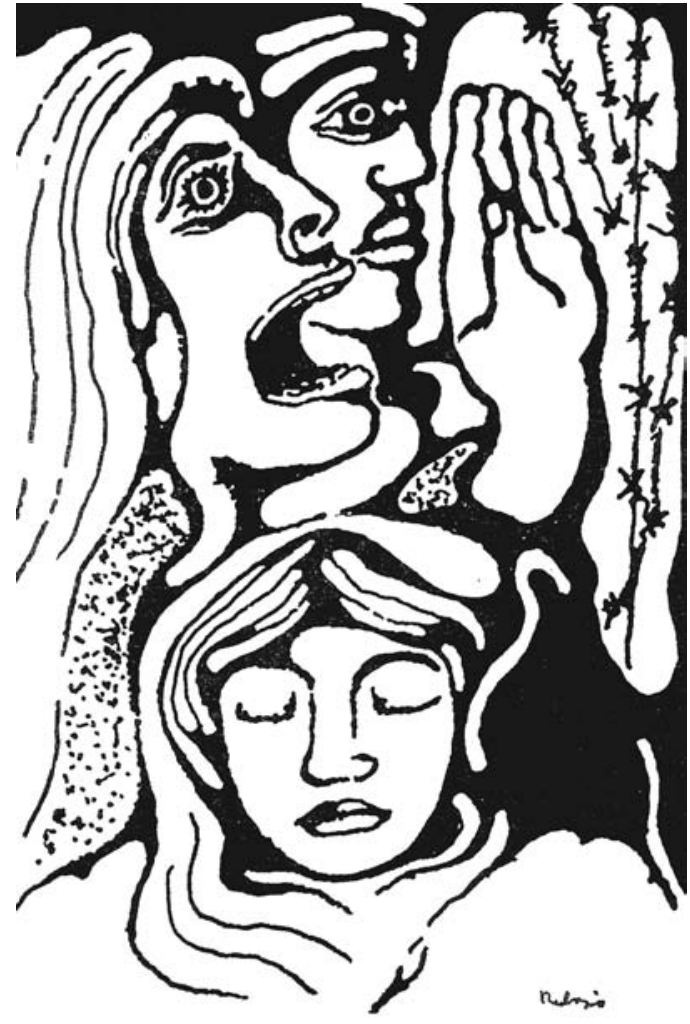

Folheto de Antigona

Desenho de

Francisco Relógio a propósito de Antigona

em sala aberta com uma espécie de sessão de grupoanálise, que sacudiu os voluntários de forma porventura excessiva. Passadas as diversas provas e improvisações, ao fim de algumas semanas, o resultado era uma espécie de teatro espontâneo de autoria colectiva, cujo valor principal era a ousadia absoluta, uma experiência ao gosto dos happenings que estavam na moda "lá fora". Na última sessão, uma personagem, que simbolizava a Igreja, abençoava uma aliança entre o General e o Capitalista! Era um exercício gratuito que podia deitar a perder o $1 .{ }^{\circ}$ Acto.

A Direcção convocou os participantes e literalmente proibiu o projecto, arrostando com as críticas que bem se imaginam. Entre os mais duros críticos, salientou-se 0 jornalista e escritor Fernando Madureira.

A terceira realização aqui seleccionada foi $A$ cantora careca, de lonesco, encenada por Carlos Nery. Uma direcção correcta e rigorosa, sem pretensões fantasiosas, valorizou a transmissão do admirável texto, por actores talentosos (entre os quais Carmen Santos), com métier e trabalho aturado. A promessa de um trabalho continuado, que não se concretizou, infelizmente, apesar de, durante meses, Nery ter ensaiado Woyzeck, de Georg Büchner, nunca apresentado.

\section{A Censura e outros "amigos"}

Cada espectáculo teatral precisava de visto da Censura como o 1. ${ }^{\circ}$ Acto era "amador", o visto sobre o texto bastava. Depois, para cada sessão, licença da Direcção Geral dos Espectáculos, pedida ao delegado concelhio, com exibição do visto.

Mas a repercussão do que ali se fazia alterou tudo: graças ao $1 .^{\circ}$ Acto, a partir de certa altura, os espectáculos de teatro amador passaram a ter ensaio de censura, como os profissionais. E o visto passou a ser mais difícil de conseguir, como se calcula. 
0 mesmo aconteceu com sessões de canções. Era a época das baladas e "baladeiros" - o mais famoso dos quais foi Zeca Afonso.

No clube seguia-se um procedimento habilidoso, aproveitando a letra da Lei de então - bastava pagar uma licença de "acto de variedades" e, a coberto dela, havia poesia, canções e o mais que se imagina. A repetição incessante e com grande êxito desses "actos de variedades" com um baladista sul-americano - Carlos, presumível refugiado político - resultou numa injunção da Censura: agora, sempre que haja textos, falados ou cantados, cada texto tem de ter o visto! Outro contributo do Primeiro Acto para o apertar da Censura!

Em fins de 1969, realizaram-se eleições para a Assembleia Nacional, as primeiras sob o governo de Marcelo Caetano, havendo alguma abertura aparente a candidaturas de oposição. Prudentemente, o Primeiro Acto decidiu não ceder o teatro para actos de propaganda eleitoral, prevendo que isso viesse a causar, após as eleições, um encerramento compulsivo. A decisão foi muito contestada, interna e externamente, por quem achava que esse desfecho seria desejável mesmo, por vergonhoso para o regime. Estas discussões apareceram relatadas por informadores, em processos encontrados na P.I.D.E., após o 25 de Abril. Em todo o caso, o grupo que fazia Antígona assumiu ir representar a peça em tournée eleitoral, sem identificar a produção do Clube. Mas, no Clube, fez-se uma sessão de poesia e canções sem qualquer referência às eleições, embora todos os intervenientes fossem notórios apoiantes da Oposição. Um deles - Deniz Cintra, irmão de Luís Miguel Cintra - exibia na viola um pequeno autocolante da CDE - movimento de oposição. Foi o suficiente para ser conduzido à esquadra e vários dirigentes do Primeiro Acto serem chamados constantemente à Polícia durante duas ou três semanas, com pretextos fúteis, sempre acabando nessa sessão de " baladas teatrais", como ficou escrito nos autos..

\section{Influentes e influenciados}

Já foi mencionado que a ideia inicial era o grupo de teatro amador, e Armando Caldas, que vinha do Teatro Moderno de Lisboa, trouxe apoios de outros membros dessa Companhia, tendo, por exemplo, Carmen Dolores, Costa Ferreira, Fernando Gusmão e Rogério Paulo acompanhado e acarinhado o projecto, já na sua configuração de Clube de Teatro.

Nomes como Adolfo Gutkin, Carlos Avilez, Jorge Listopad e outros que se considerava que apontavam caminhos para o Teatro em Portugal, vieram ajudar, pelo menos a pensar nesses caminhos. Do estrangeiro, era muito forte o Maio de 68, mas falava-se com entusiasmo em Julian Beck, no Living Theatre, em Grotowski...

0 traço essencial do $1 .{ }^{\circ}$ Acto era mesmo o Clube, a placa giratória de pessoas e influências, que por vezes o atravessavam sem deixar rasto. 0 espaço de encontro em liberdade foi talvez o factor que deixou mais importante legado, pois constituiu muitas vezes a oportunidade desse encontro que melhora as pessoas e a sua intervenção social, podendo dizer-se que houve aí um pequeno contributo para a revolução que surgiu anos mais tarde. Isto, mesmo nas pessoas já calhadas em coisas mais ou menos subversivas, pelas condições que os programas e o espaço ofereciam.

Mas, para quem estava fora de tudo isso, mal conhecia o teatro que se fazia em Portugal, e o que ele queria reflectir, foi um acordar de consciência e de atenção para o teatro como meio de informação e para a cultura como valor da identidade e da identificação, numa sociedade que reprimia a comunicação entre as pessoas.

Este efeito não foi o mais ruidoso mas, volvidos quase quarenta anos, foi porventura o mais duradouro e significativo para o Teatro. 